\title{
Computerized pre-listening activities and the comprehension of English narrative texts
}

\author{
Mahbube Keihaniyan \\ Department of English, Najafabad Branch, Islamic Azad University, Isfahan, Iran \\ Email address: \\ m_keihaniyan@yahoo.com
}

To cite this article:

Mahbube Keihaniyan. Computerized pre-Listening Activities and the Comprehension of English Narrative Texts. Education Journal. Vol. 2, No. 4, 2013, pp. 132-137. doi: 10.11648/j.edu.20130204.15

\begin{abstract}
This study investigated 60 female and male learners in 3 groups of 20 who were selected by a Nelson test, to determine whether computerized pre listening activities, the use of key vocabulary and pictures, have a significant effect on the comprehension of English narrative texts. Also, was there any significant difference between the two computerized prelistening activities in terms of their effect on comprehension of English narrative texts? To do this, a computer assisted language learning (CALL) software, RFLX 2013, was employed for the purpose of the study. All participants listened to four different narrative passages via a computer. Each experimental group was exposed to one of two computerized pre listening activities. After listening, subjects answered a five item true-false test and a five item multiple-choice test. Finally an ANOVA and a t-test were used to analyze the data. The results of this study showed that both types of computerized activities have significant effects on the listening comprehension of English narrative texts. Using multimedia software can help listeners to make a bridge between what they already know and what they are supposed to learn.
\end{abstract}

Keywords: Computerized Activities, Pre Listening Activities, Narrative Texts, Multimedia Software

\section{Introduction}

Language teaching came into existence as a profession in the twentieth century. Its foundation was developed during the early part of the twentieth century as applied linguists focused on the fields of linguistics and psychology to support what was thought to be a more effective teaching methodology. Language teaching in the twentieth century was characterized by frequent changes, innovations and development of language teaching ideologies (Richards \& Rodgers, 2003).

The abundance of methods derived from different theoretical standpoints has led to the emergence of a field known as methodology. The term methodology is employed interchangeably with method and pedagogy. Language teaching methodology encompasses methods such as direct method, audiolingualism, community language learning, etc., but it is not limited to those methods that are widespread in application. Methodology also includes methods that might be developed and employed by one teacher, provided there is a rationale behind the procedures of the method. The popularity of some methods is not necessarily an indication of their inherent quality (Richards \& Rodgers, 2003).
Despite the claims of proponents of some methods, no consensus has emerged as the best way to teach a language; there have been some ideas to abandon what Richards (2002, as cited in Davies, 2006) calls the super method and to concentrate on equipping teachers with a repertoire of methods and skills that can be used in different contexts.

\section{The Importance of Listening}

Teachers who want to provide the most effective classroom experience for their second language students should consider this: No other type of language input is as easy to process as spoken language, received through listening (Richards \& Schmidt, 1983). At the beginning stages of language study, before students have learned to read well, it is by listening that they can have the most direct connection to the meaning of a new language. Through listening, learners can build an awareness of the interworking of language systems at various levels and thus establish a base for more fluent skills.

At the intermediate level, when students are refining their understanding of the grammatical system of their second or foreign language, listening can be used to stimulate awareness of detail and to promote accuracy. At advanced levels, when students are able readers and written language 
has become a viable source of input, listening should still occupy a central place in their language use. A regular program of listening can extend learners' vocabulary and use of idioms and build their appreciation for cultural nuances. Moreover, successful academic study in English requires a mastery of the listening demands in formal lectures as well as in interactive exchanges which are common to seminar settings and conversational lecture styles.

\section{Listening and Technologies}

A prominent artifact of older beliefs concerning the role of listening in language is language laboratory. The rationale for language laboratories is tied to the notion that individual listening practice with audiotape helps build a learner's ability to understand and speak the target language. Technology continues to be perceived as an enhancement to the process of language acquisition. The large scale infusion of computers in language instruction programs in the past decade attest to this belief (Rieber, 1991). The rationale behind what is what is now growing support for Computer Assisted Language Learning (CALL) is not unlike earlier enthusiasm for audiotape-based technologies. That is, both media provide individualized access to target language material that the learner can control and use in a self study format. However, expectations for CALL in general and multimedia in particular are much higher. Fast and powerful computational capacity, in conjunction with multimedia learning systems would predict more sophisticated paradigms within which students can interact with the target language and, consequently, more effective learning.

\section{Schema}

A schema is a cognitive framework or concept that helps organize and interpret information. Schemas can be useful because they allow us to take shortcuts in interpreting the vast amount of information that is available in our environment. However, these mental frameworks also cause us to exclude pertinent information and to instead focus only on things that confirm our pre-existing beliefs and ideas. Schemas can contribute to stereotypes and make it difficult to retain new information that does not conform to our established ideas.

\section{Statement of the Problem}

In spite of the potential of computer technology in facilitating second language (L2) learning, many attempts have not been made in Iran to develop computer programs which would facilitate learning English as a foreign language. It is also worth noting that the use of technology in English language education has been limited, and also studies on the effectiveness of CALL have rarely been conducted in Iran. Regarding listening comprehension, English as a foreign language (EFL) learners experience considerable difficulty in comprehending English texts when listening to them for the first time. According to the schema theory, the main reason for this problem is that there is a gap between a reader's prior knowledge and the knowledge in the text. Stipek and Ryan (1997) suggest that the gap can be bridged by giving listeners (before having them listen to a text) some materials or activities as pre listening activities in order to provide them with and / or activate the necessary prior knowledge. While the effects of these non-computerized pre listening activities on listening comprehension have usually been shown to be positive (Cunninghum, 2008), a few studies have examined the effects of computerized pre listening activities on listening comprehension. Also, many studies have been conducted for the sake of comparing these activities to understand which one has a more significant effect on comprehension of narrative texts among Iranian EFL learners.

\section{Direct Method}

Direct method was developed in the late $19^{\text {th }}$ century as a reaction against the Grammar Translation Method and was the first oral-based method to become widely adopted. This method has these features:

1) only the target language should be used in class.

2) meanings should be communicated directly.

3) reading and writing should be taught only after speaking.

4) grammar should only be taught inductively.

\section{Audio-Lingual Method}

A method of foreign or second language teaching which (1) emphasizes the teaching of speaking and listening before reading and writing (2)uses dialogues and drills (3) discourages use of the mother tongue in the classroom (4) often makes use of contrastive analysis.

\section{Community Language Learning}

A method of second and foreign language teaching developed by Charles Curran. Community language learning is an application of counseling learning to second and foreign language teaching and learning. It uses techniques developed in group counseling to help people with emotional problems.

\section{Objectives of the Study}

In this study, an attempt has been made to determine whether the listening comprehension of narrative texts improves when students use multimedia CALL soft ware (RFLX, 2013). This software provides learners with 2 different pre listening activities, the use of key vocabulary and pictures. It is also intended to find out which of the above two activities plays a more significant role in improving comprehension of narrative texts. 


\section{Research Questions}

With regard to what has been presented above, the present research will address two major questions:

1) Do computerized pre listening activities, the use of key vocabulary and pictures, have a significant effect on the comprehension of English narrative texts?

2) Is there any significant difference between the two computerized pre listening activities in terms of their effect on comprehension of English narrative texts?

\section{Significance of the Study}

Since little has been done on computer integration in to EFL curricula in general and EFL listening in particular, the findings of this research are useful for teachers who use computers in their classroom. Today's teachers can not let a technological revolution pass by without using it to serve their language teaching goals. Since teachers seek to help their students become independent learners, these programs are very useful for teachers as well as students.

Computerized pre listening activities such as picture content and new vocabulary as well as non-computerized ones are intended to help EFL learners overcome their comprehension problems of narrative texts. Pre listening activities together with pictures may help reduce some of these distortions. Moreover, in a situation such as in our country, where knowledge is extracted via increasingly prevailing texts on the internet and other sources, it seems essential to find ways to improve the students' ability to comprehend English texts at all academic levels. Moreover, the use of a computer enables the instructor to provide the students with more opportunities than those presented to students in a more traditional classroom setting.

\section{Participants}

The participants of this study ranged from 15 to 17 year-old students selected randomly from 150 EFL students studying English as a foreign language (EFL) in a private English institute in Najafabad their scores on the Nelson test were between one standard deviation above and below the mean. The participants were 60 female and male learners in 3 groups of 20 . They were all native speakers of Persian.

\section{Instruments}

Data in this study were collected using the following instruments:

1) A Nelson test (1999, as cited in Dadkhah's thesis, 2002). It consisted of 40 multiple-choice items on grammar and vocabulary to estimate the proficiency level of the learners.

2) Reading passages

Four English passages, all being of a narrative kind were taken from the World English 3 book by Lesely, et al. (2011). The passages were not too long for the time constraints of the experiment. Four selected passages were entitled: Saving a City's Public Art, Survival School, The Carbon Connection, and A Delicacy to Die FOR. The reason for selecting different topics was to make sure that the subjects would need different kinds of background knowledge and therefore, remove potential biases.

3) RFLX2013

This software (RFLX, 2013) developed by computer experts was used for the purpose of this study. In development of the software, the capability of multimedia CALL in combining different modalities was used and the emphasis was on the use of picture and key vocabulary as two different pre listening activities for activating the prior knowledge of learners. This is used for conducting computerized pre listening activities, listening texts, and final assessment of listening comprehension.

\section{Data Collection and Procedure}

After selecting 60 homogenous participants based on the results of the Nelson test, they were randomly assigned to two experimental groups and one control group of 20. Then each experimental group received specified computerized pre listening instruction, use of key vocabulary and picture, by means of the RFLX 2013 software for all of the texts. Control group students were given no computerized pre listening instruction, but were simply asked to listen to the texts via a computer and then answer the comprehension questions. The treatment sessions took two months.

\section{Inferential Statistics}

In order to address the first research question, it was important to make sure that all groups had a normal distribution. A Levene's test of equality of error variance in SPSS was used to demonstrate the normality of the groups:

Table 1. The Homogeneity of Variances

\begin{tabular}{ccccc}
\hline & $\begin{array}{c}\text { Levene } \\
\text { statistic }\end{array}$ & df1 & df2 & significance \\
\hline $\begin{array}{c}\text { Pictorial context } \\
\text { Key vocabulary pre- } \\
\text { listening }\end{array}$ & 3.80 & 3 & 5 & 0.60 \\
\hline
\end{tabular}

As Table 1 displays, the significance value was 0.60 and 0.90 , respectively. Therefore, the assumption of the equality of variance is not rejected at 0.05 . As a result, according to the Levene's test, the two groups had a normal distribution. The normality of the dependent variable (the listening comprehension scores) was also investigated by the significance value of kolmogorov-smirnor for the two groups with the sample of sixty participants: 
Table 2. One-sample kolmogorov-smirnor Test

\begin{tabular}{cccc}
\hline & Control group & $\begin{array}{c}\text { Key } \\
\text { vocabulary } \\
\text { pre-listening }\end{array}$ & $\begin{array}{c}\text { Pictorial } \\
\text { context }\end{array}$ \\
\hline $\mathrm{N}$ & 20 & 20 & 20 \\
Mean & 23.60 & 32.20 & 40.70 \\
Std.Derivation & 2.90 & 3.70 & 3.50 \\
Absolute & .120 & .150 & .130 \\
Positive & .120 & .150 & .130 \\
Negative & -.180 & -.140 & -.130 \\
kolmogorov-smirnor & .470 & .60 & .52 \\
Asymp.sig (2-tailed) & .970 & .85 & .94 \\
\hline
\end{tabular}

As Table 2 displays, the p-value of this test was greater than .05 for each test. Therefore, the normality assumption is not rejected at 0.05 . The test of the normality indicated that all groups were normal. To address the first research question, a one way ANOVA was conducted. Each experimental group was an independent random sample from a normal population and by conduction of Levene's homogeneity of variance test, it was revealed that groups came from populations with equal variances.

The listening comprehension test scores were considered as the dependent variable, and the type of treatment, key vocabulary pre listening and pictorial context, considered as the independent variable for the listening comprehension test scores. The purpose was to see the effect of the two computerized pre listening activities, key vocabulary pre listening and pictorial context, on listening comprehension test scores.

Table 3. Analysis of Variance on the Listening Comprehension Scores for the Effect of Treatment

\begin{tabular}{cccccc}
\hline Sig & F & $\begin{array}{c}\text { Mean } \\
\text { square }\end{array}$ & df & $\begin{array}{c}\text { Sum of } \\
\text { squares }\end{array}$ & \\
\hline & & & & & Between \\
& & & & & groups \\
& & & 57 & 450.9 & Within groups \\
& & 109050 & 2 & 2604.00 & Total \\
\hline
\end{tabular}

As Table 3 shows, the F-value for the pre listening activity was $90.7 \quad(\mathrm{p}<0.05)$, so the effect of computerized pre listening activities, key vocabulary pre listening and pictorial context, was significant on the listening comprehension test mean scores. This result also indicates that there was a significant difference between two groups. That is, two methods of computerized pre listening instruction did not have the same effect on the listening comprehension test scores.

According to Hatch and Farhady (1981), the statistical analysis of the test could help the researcher be confident that the difference between the performances of the two groups was not due to chance or sampling error. To investigate the second research question, a sample t-test was run to compare the mean scores of the two experimental groups (Table 4). The listening comprehension test scores were considered as the dependent variable and the type of task, key vocabulary pre listening and pictorial context, was considered as the independent variable for the listening comprehension test scores:

Table 4. T-Test Statistics on the Differences between the two Experimental Groups of the Study

\begin{tabular}{ccccc}
\hline Group & $\begin{array}{c}\text { Mean } \\
\text { Difference }\end{array}$ & $\begin{array}{c}\text { Sig } \\
\text { (2-tailed) }\end{array}$ & df & t \\
\hline $\begin{array}{c}\text { Pictorial Context } \\
\text { Key Vocaulary }\end{array}$ & 40.70 & .000 & 19 & 44.60 \\
Pre-listening & 30.260 & & & \\
\hline
\end{tabular}

As Table 4 reveals, the difference between the mean scores of the pictorial context group $(\mathrm{m}=40.7)$ and key vocabulary pre listening group $(\mathrm{m}=30.26)$ is statistically significant $(\mathrm{t}=44.60, \mathrm{df}=19$, two- tailed $\mathrm{p}<0.05)$.

\section{Discussion}

It has always been difficult to carry out research on language learning as a matter of human behavior because different dimensions of human characteristics such as psychology, social behavior, culture, and so forth must be considered (Reynolds \& Carson, 2005).

The First Research Question: Do the computerized prelistening activities, the use of key vocabulary and pictures, have a significant effect on the comprehension of English narrative texts?

The first null hypothesis: The computerized pre listening activities, the use of key vocabulary and picture, do not have a significant effect on the listening comprehension mean score of English narrative texts.

According to Best (1977), since the mean is probably the most satisfactory measure for characterizing a group, the researcher found it important to determine whether the difference between the mean of the sample groups was significant. According to the results, the mean scores of two experimental groups were significantly higher than the mean scores of the control group. To compare the mean scores of the three groups of the study, a one way ANOVA was run. Since the F-observed value is greater than the critical F-value and also probability level, the first null hypothesis is rejected. Thus, it can be concluded that there is a significant difference between the mean scores of the three groups on the listening comprehension test. As a result, it could be argued that computerized pre listening activities have a significant effect on the listening comprehension of narrative texts. Also, Wise, Ring and Olson (2009) MacArthur, Ferretti, Okolo and Cavalier (2007), Hecht and Close (2002), Cassady and Smith (2004), Foster, Erickson, Forster, Brinkman and Torgensen (2002), Macaruso and 
Valker (2008), Mitchell and Fox (2001), Reitsms and Wesseling (2003) found that computer technology has led to significant improvement of participants in listening comprehension development. There are a variety of reasons which could be presented to explain the experimental groups' progress in listening comprehension. First, using multimedia technology to simultaneously present the audio, visual and textual information to the learners according to studies such as King and Dennis (2003), leads to higher immediate and delayed posttest scores in comparison with learners who have access to merely textual information. Another possible reason for this benefit might be attributed to the characteristics of computer - based instruction, such as individual instruction, monitoring, and immediate feedback.

The Second Research Question: Is there any significant difference between the two computerized pre listening activities in terms of their effect on comprehension of English narrative texts?

The Second null hypothesis: There is no significant difference between the effect of the two computerized pre listening activities, the use of key vocabulary and picture, on the listening comprehension mean scores of English narrative texts.

Listening and understanding foreign language text require not just the decoding of words one by one, but going beyond the word level to consider the connections the writer establishes among those words to create larger units of meaning. Using multimedia software such as RFLX 2013, helps students better understand a passage by activating their background knowledge and giving them the opportunity to interact with the text and to explore the supporting information on their own. Concerning the second null hypothesis, and in order to compare the mean scores of the two experimental groups, a one sample t-test was run. According to the results, the mean score of the pictorial context group in the listening comprehension tests was much higher than those of the key vocabulary pre listening group. According to Table 4 the t-value was significant. This means that there was a significant difference between the mean score of the pictorial context group and key vocabulary pre listening group in the listening comprehension test scores. Thus, the second null hypothesis of this study is rejected. The above findings indicate that using pictures and visual aids as a pre listening activity in a computerized format is more effective than teaching key vocabulary. The results of this study also confirm the results of the previously mentioned studies which had shown that the various modalities of multimedia such as text picture, video, and sound do not have the same (quantitative and qualitative) capacities in improving the learning of vocabulary and consequently improving the listening comprehension of a second/ foreign language (Al-Seghayer, 2001; Babaie, 2010). In order to understand why the scores were higher in the computer assisted pictorial context group, one also could refer to the dual-coding theory presented by Paivio (2001). According to this theory, memory and cognition are served by two independent and separate systems, one of which deals with verbal information, such as the words in printed text or speech sounds, and the other deals with nonverbal information, like pictures and visible objects and environmental sounds. According to Paivio and Egg (2002), although the two systems are separate and independent, they are interconnected and thus representations in one system can activate those in the other. Based on the dual-coding theory, using multimedia technology to present nonverbal audio visual information causes easier activation of the verbal information. Consequently, it will be quite logical that learners using the multimedia CALL treatment learn and remember the new words and concepts of a second / foreign language listening text better than the students learning through the conventional treatment in the simple setting of a classroom. Another justification is that visuals might help learners remember the meanings of keywords in listening passages. According to Babaie (2010), visuals compared with textual are more elaborate in nature, and hence might better reveal the underlying concepts with which words are associated. When applied to listening comprehension, students might arrive at an even better understanding of listening passages, as the meanings of keywords and concepts are more effectively revealed to them.

Yet another explanation is that pictures are effective attention getting devices. Day (2000) argues that visuals have the potential to arouse students' curiosity as they attempt to analyze the concepts with which pictures are associated. This stimulation of curiosity might more effectively focus learners' attention on the subject matter being introduced, which in the long run might lead to an even more effective acquisition of information. When applied to listening comprehension, the researcher of the present study believes that increased levels of attention on keywords and main concepts before listening to the passage can persist in learners' working memory, hence making the associated meanings more memorable. Accordingly, as students more readily keep track of the meanings in their memory, they may arrive at an even deeper understanding of the passages.

\section{Conclusion}

Listening to a foreign language is not an easy task, especially for beginning and intermediate - level students. It seems, however, that the use of multimedia technology for conducting pre listening activities can facilitate foreign language in a number of ways. It also seems that for computer - assisted listening activities, computerized pre listening activities have the potential to actively engage students in learning because of their capabilities to allow repeated practice with instant feedback, to allow students to work at their own pace, to provide them with interactive listening tasks, and to help them perceive the value of success. The present study has investigated the effect of computerized pre listening activities, use of picture and key vocabulary, in the listening comprehension of English narrative texts. Also RFLX 2013 software was employed to 
facilitate listening comprehension of the determined texts.

\section{References}

[1] Al-Seyghayer, K. (2001). The effect of multimedia annotation modes on L2 vocabulary acquisition: A Comparative Study, Language Learning and Technology, 5,202-232.

[2] Babaie, H. (2010). Image modalities in multimedia vocabulary instruction: does dual coding of vocabulary occure at different degrees? Journal of English language Studies.

[3] Best, R. (1997). Children's text comprehension. Effect of genre, knowledge, and text cohesion. In S.A. Barab, K. E. Hay, and D.T. Hickey (Eds.), proceedings of the seventh international conference of the learning sciences (pp.37-42).

[4] Carrell, Patricia. L. \& Eisterhold, Joan. C. (1983). Schema theory and ESL reading pedagogy. TESOL Quarterly, 17 (4), 553-573.

[5] Cassady, J.C., \& Smith, L.L (2004). The impact of a reading-focused integrated learning system on phonological.

[6] Chun, D., \& Plass, J. (1996). Effects of multimedia annotations on vocabulary acquisition. The Modern Language Journal, 80(2), 183-198.

[7] Cunningham, A.E. (2008). Early reading acquisition and its relation to reading experience and ability years later. Developmental Psychology, 33: 934-945.

[8] Dadkhah, (2002). The relationship between test anxiety and sex. Unpublished master's thesis, University of Khoramabad, Khoramabad, Iran.

[9] Day, I. (2000). Curiosity and the Interested Explorer, performance and instruction, 21 (4), 19-22.

[10] Foster, K.C., Erickson, G.C, Forster, D. F., Brinkman, D., \& T. regensen, J.K. (2002). Computer administered instruction in phonological awareness: Evaluation of the DaisyQuest of the Daisy Quest program. Journal of Research and Development in Education, 27, 126-137.

[11] Hatch, E. and Farhady, H. (1982). Research Design and Statistics. Newburg house publisher INC.

[12] Hecht, S.A., \& Close, L. (2002). Emergent literacy skills and training time uniquely predict variability in responses to phonemic awareness training in disadvantaged kinder gartners. Journal of Experimental Child Psychology, 82, 93-115.

[13] King, S.H. and Dennis, J.R. (2003). The effect of computer-enhanced vocabulary lessons on achievement of ESL grade school children, computer in the school, 11(3), $25-32$.
[14] Lesely, T., Hansen, C., \& Zukowski, J. (2005). Interchange Passages, Placement and Evaluation Package, Cambridge University Press, England.

[15] MacArthur, C.A., Ferretti, R. P.Okolo, C.M., \& Cavalier, A.R. (2007). Technology applications for students with literacy problems: A critical review. Elementary School Journal, 101, 273-301.

[16] Macaruso, P., and Walker, A. (2008). The efficacy of computer assisted instruction for advancing literacy skills in kindergarten children. Reading Psychology, 29,266-287.

[17] Mitchell, M.J., \& Fox, B, J. (2001). The effects of computer software for developing phonological awareness in low-progress readers. Reading Research and Instruction, 40(4), 315-332.

[18] Osborne, H. (2000), assessing readability: Rules for playing the numbers game, December.

[19] Paivio, A. (2001). Imagery and Verbal Processing, New York: Holt, Rinehart, and Winston.

[20] Pavio, A., and Begg, I. (2002), Psychology of Language, Englewood Cliffs, NJ: Prentice Hall.

[21] Reitsma, P., \&Wesseling, R. (2003). Effects of computer assisted training of blending skills in kindergartens. Scientific Studied of Reading, 2(4), 301-320.

[22] Reynolds, C. R., \& Carson, A. D. (2005). Methods for assessing cultural bias in tests. In C. L. Frisby \& C. R. Reynolds (Eds.), Comprehensive handbook of multicultural school psychology (pp. 795-840). Hoboken, NJ: Wiley

[23] Richards, J. C., \& Rodgers, T. S. (2003). Approaches and Methods in Language Teaching. Cambridge: Cambridge University Press.

[24] Richards, J. C., \& Schmidt, R. (Eds.). (1983). Language and communication. London: London Group, Ltd.

[25] Rieber, L. P. (1991). The effects of computer animated lesson presentations and cognitive practice activities on young children's learning in physical science. In Proceedings of selected research papers presented at the Annual Meeting of Association for Educational Communications and Technology. (ERIC Document Reproduction Service No. Ed 308833).

[26] Stipek, D., \& Ryan, R. (1997). Economically disadvantaged preschoolers: Ready to learn but further to go. Developmental Psychology, 33(4), 711-723.

[27] Wise, B. W., Ring, J., \&d Olson, R. K. (2009). Individual differences in gains from computer-assisted remedial reading. Journal of Experimental Child Psychology, 77, 197-235. 